International Journal of Health Sciences
Available online at www.sciencescholar.us
Vol. 6 No. 1, April 2022, pages: 21-31
e-ISSN: 2550-696X, p-ISSN: 2550-6978
https://doi.org/10.53730/ijhs.v6n1.3027

\title{
Anxiety and Depression Disorders on Health Workers in COVID and Non-COVID Wards of Sanglah Hospital
}

\author{
CrossMark \\ Ni Ketut Putri Ariani a, Cokorda Bagus Jaya Lesmana b, Amita Rouli Purnama Sitanggang c, \\ Imelda Loren M Pasaribu ${ }^{\mathrm{d}}$
}

Manuscript submitted: 6 August 2021, Manuscript revised: 9 November 2021, Accepted for publication: 18 December 2021

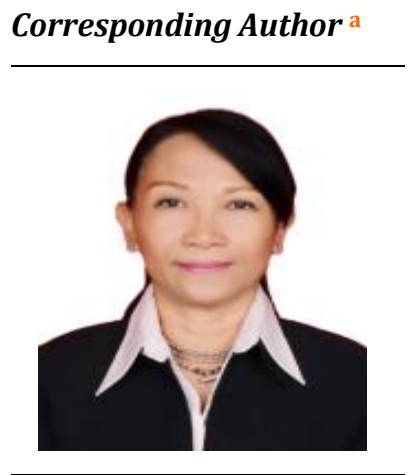

Keywords

anxiety;

clinical health;

COVID-19;

depression;

health emergency;

health system;

health workers;

healthcare organization;

\section{Abstract}

This study aims to determine anxiety and depression among health workers during the COVID-19 pandemic at Sanglah Hospital. Health workers in the front line on the COVID-19 pandemic are at high risk of being infected and at high risk of psychological impact. A descriptive study with a crosssectional design and an online survey was conducted using the Beck Depression Inventory (BDI) instrument, and Beck Anxiety Depression (BAI). A total of 188 health workers were included. In this study, 3.7\% of the participants had mild mood disorders, $1.1 \%$ had clinical depression and $0.5 \%$ had severe depression. Health workers who do not deal directly with COVID patients have a greater percentage of depression (2.04\%) compared to those who have direct contact $(1.4 \%)$. Statistically, occupation was significantly associated with the incidence of depression $(p=0.044)$. It was found that $18.1 \%$ has anxiety and the highest level of anxiety was found in nurses $(20.8 \%)$ and also in participants who worked in the Non-COVID ward (24.5\%). There is a statistical significance between anxiety and work station $(\mathrm{p}=$ 0.064).

International Journal of Health Sciences (C) 2022. This is an open access article under the CC BY-NC-ND license (https://creativecommons.org/licenses/by-nc-nd/4.0/).

\section{Contents}

Abstract.

1 Introduction

2 Materials and Methods

3 Results and Discussions

a Udayana University and Sanglah General Hospital, Denpasar, Indonesia

b Udayana University and Sanglah General Hospital, Denpasar, Indonesia

c Udayana University and Sanglah General Hospital, Denpasar, Indonesia

d Udayana University and Sanglah General Hospital, Denpasar, Indonesia 


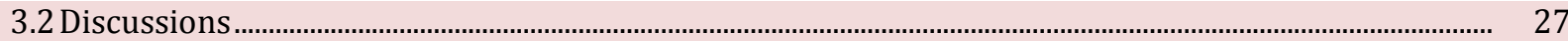

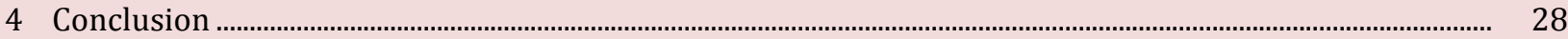

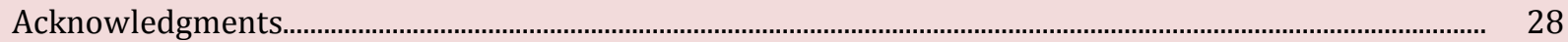

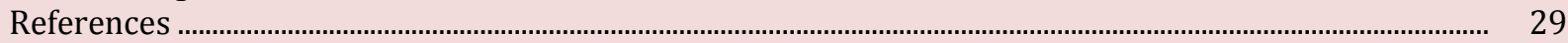

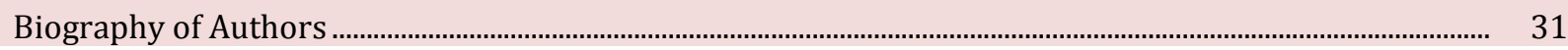

\section{Introduction}

SARS-CoV 2, a new coronavirus that causes severe acute respiratory disease in humans, has become a worldwide health emergency, with the World Health Organization (WHO) declaring a pandemic in March 2020. Since its discovery in Wuhan, China, in December 2019, this virus has spread fast throughout the world. According to the Johns Hopkins University Center for Systems Science and Engineering, COVID-19 afflicted 216 nations, with more than 42 million positive confirmed cases and more than 1,1 million confirmed COVID19 deaths. The number of instances suggests that the global health system may be overwhelmed by COVID19. In dealing with COVID-19, health workers are on the front lines and must be protected as each country's health professionals (Tetro, 2020).

The COVID-19 virus has spread to almost all countries to illustrate the interconnectedness of the world (Burdorf et al., 2020). Although COVID-19 has become a global concern since December 2019, the world was still not ready when this disease became a global pandemic in the early months of 2020 (Del Rio \& Malani, 2020). This pandemic is also spreading rapidly in Indonesia, one of which is in Bali, emphasized the limitation of activities for residents by studying, working (both government administration administrators, as well as business/private activities), worship at home. The spread of COVID-19 in Bali is very fast due to many factors, so the Governor of Bali issued a Decree dated March 23, 2020, in the form of adding a COVID-19 Referral Hospital in Bali, one of which is Sanglah Hospital.

In terms of health workers, they must be ready at the frontline providing medical care. This pandemic greatly affects the clinical health of the health workers themselves, because it involves many factors including stress and fatigue (Brooks et al., 2020). These factors could have a negative impact on patient care and lead to increased medical errors, malpractice, and early retirement. Greater clinical stress can lead to higher rates of drug and alcohol addiction, divorce, and suicide (Nanda, 2020).

Not only is the level of stress high on the job, but healthcare organizations are also under immense pressure and many are still struggling to deal with critically ill patients concurrently. Health workers are at higher risk of being exposed to the virus because of their contact with COVID-19 patients, who are at risk of infection. At the same time, health workers themselves are a source of disease transmission to colleagues, patients, friends, and family (Rose, 2020; Akbarov et al., 2021).

Then, problems arise with self-isolation, fear of symptoms, and worries of bringing the disease home to loved ones. It is necessary to consider providing alternative accommodation to help health workers to reduce the fear of exposing their families at home. There is no clear evidence as to which health workers will be most stressed during their quarantine, so it is best to provide psychosocial support to all health workers (Haines et al., 2007). Previous research has shown that lack of adequate information and the higher the number of confirmed cases, the higher the demand for health care (Nanjundaswamy et al., 2020; Martini et al., 2004; Huang \& Zhao, 2020). This condition places health workers at risk of psychological disorders due to various reasons, including: facing an unprecedented risk of occupational morbidity and mortality, lack of and/or adequate PPE, exposure to infected patients, work overload, poor infection control, caring for health workers. infected patients and concerns about the risk of transmitting the infection to their families and themselves (Tan et al., 2020; Dyrbye et al., 2008; Neumann et al., 2011; Shanafelt et al., 2012). The causes of these psychological disorders will have an impact on the mental health of health workers. This study focused on finding out how the symptoms of anxiety and depression are described by health workers in the COVID and non-COVID wards at Sanglah Hospital (Warren et al., 1997). 


\section{Objectives}

The results of this study could provide an overview of the level of anxiety and depression in health workers in service during the COVID-19 pandemic, which can be used as one of the considerations and foundations for HR management in hospitals and the government to improve the performance and quality of life of health workers, especially in RSUP Sanglah.

\section{Materials and Methods}

The research method uses a quantitative approach with a descriptive type with a cross-sectional design for health workers at Sanglah Hospital from April to October 2021. The data collection method uses the Beck Depression Inventory (BDI) and Beck Anxiety Depression (BAI) online instruments. The target population is all health workers in the COVID and non-COVID wards of Sanglah Hospital Denpasar. The affordable population is health workers in the COVID and non-COVID wards of Sanglah Hospital Denpasar who work from April 2021 to October 2021. Inclusion criteria are health workers who work at Sanglah Hospital in the period April 2021 to October 2021. Exclusion criteria were health workers who refused to participate in the study after reading the informed consent and had a history of psychiatric disorders before April 2021. The data from the research instrument were collected and inputted into SPSS 25 in stages, to be processed into descriptive data to calculate the anxiety and depression scores of the respondents.

\section{Results and Discussions}

\subsection{Result}

A total of 188 participants of health workers at Sanglah Hospital were included in this study. In this study, participants were aged between 21 to 60 years with a mean age of 34 years and most participants came from the age group 21-30 years (46.8\%). The sample is dominated by women $(70.7 \%)$, the dominant occupation is a nurse (51.1\%) and participants work in the COVID treatment room (73.9\%). Most of the samples are married (71.3\%). Participants' BAI scores ranged from 0 to 39, while BDI scores ranged from 0 to 33 in this study.

Tabel 1

Demography

\begin{tabular}{lcc}
\hline Sex & $\mathrm{N}=188$ & $(\%)$ \\
\hline Male & 55 & 29.3 \\
Female & 133 & 70.7 \\
Degree & & \\
Diploma & 57 & 30.3 \\
Graduate & 118 & 62.8 \\
Postgraduate & 10 & 5.3 \\
Doctoral & 3 & 1.6 \\
Occupation & & \\
Resident & 78 & 41.5 \\
General Practitioner & 1 & 0.5 \\
Specialist & 7 & 3.7 \\
Nurse & 96 & 51.1 \\
Midwife & 2 & 1.1 \\
Others & 4 & 2.1 \\
\hline
\end{tabular}

Ariani, N. K. P., Lesmana, C. B. J., Sitanggang, A. R. P., \& Pasaribu, I. L. M. (2022). Anxiety and depression disorders on health workers in COVID and non-COVID wards of Sanglah Hospital. International Journal of Health Sciences, 6(1), 21-31. https://doi.org/10.53730/ijhs.v6n1.3027 


\begin{tabular}{lcc}
\hline Workplace & & \\
COVID Ward & 139 & 73.9 \\
$\quad$ Non COVID Ward & 49 & 26.1 \\
Marriage Status & & \\
$\quad$ Married & 134 & 71.3 \\
Singles & 52 & 27.7 \\
Divorced & 1 & 0.5 \\
Widow & 1 & 0.5 \\
Age (y/o) & & \\
$21-30$ & 76 & 46.8 \\
$31-40$ & 73 & 34.0 \\
$41-50$ & 19 & 9.5 \\
$51-60$ & 20 & 9.5 \\
\hline
\end{tabular}

In this study, the BDI questionnaire was used to assess the level of depression and the BAI to assess the level of anxiety. Based on the BDI questionnaire, $94.7 \%$ of participants did not experience depression, while $4.8 \%$ of participants were found to have depression, either in the form of mild mood disorders (3.7\%), moderate depression (1.1\%), and severe depression (0.5\%). Meanwhile, based on the BAI questionnaire, it was found that $81.4 \%$ of participants experienced minimal anxiety levels, while $18.1 \%$ experienced anxiety, either mild anxiety (12.2\%), moderate anxiety (5.3\%), and severe anxiety (1.1\%). (Table 2 and Table 3 )

Table 2

Depression in health workers in COVID ward and non-COVID ward

\begin{tabular}{llccc}
\hline & & BDI & $\mathrm{n}$ & $\%$ \\
\hline Depression Score & No signs & $1-16$ & 178 & 94.7 \\
(BDI) & Mild & $17-20$ & 7 & 3.7 \\
& Moderate & $21-30$ & 2 & 1.1 \\
& Severe & $>31$ & 1 & .5 \\
\hline
\end{tabular}

Table 3

Anxiety in health workers in COVID ward and non-COVID ward

\begin{tabular}{lllcc}
\hline & & BAI & n & $\%$ \\
\hline Anxiety Score & No signs & $0-7$ & 153 & 81.4 \\
(BAI) & Mild & $8-15$ & 23 & 12.2 \\
& Moderate & $16-25$ & 10 & 5.3 \\
& Severe & $26-63$ & 2 & 1.1 \\
\hline
\end{tabular}

It was found this study based on gender found higher levels of anxiety and depression in women compared to men, anxiety levels of $20.3 \%$ and depression rates of $6.7 \%$. In the education variable, there is a high level of anxiety in undergraduate education (21.2\%) and the level of depression (6.7\%). In the occupational variable, there was the highest level of anxiety in nurses $(20.8 \%)$ and the highest level of depression in other health workers (25\%), but participants from other health workers were only 4 people, so this result does not seem very significant because the number of samples is very small. Based on the workplace, it was found that the number of participants who worked face-to-face with COVID patients in the COVID treatment room was 139 participants who did not face to face as many as 49 participants. Of the 139 participants who worked in the COVID room, it was found that $16.5 \%$ of the participants had anxiety, although the highest level of anxiety was found in the participants who worked in the non-COVID room (24.5\%). In the marital status variable, it was found that the level of anxiety was high in the unmarried participants, namely $25 \%$ of 52 participants and the depression level in the unmarried (11.5\%). (Table 4) 
Table 4

Overviews on depression and anxiety level (\%)

\begin{tabular}{|c|c|c|c|c|c|c|}
\hline & \multicolumn{3}{|c|}{ Anxiety } & \multicolumn{2}{|c|}{ Depression } \\
\hline & & $\mathrm{n}$ & $\mathrm{n}$ & $\%$ & $\mathrm{n}$ & $\%$ \\
\hline \multirow[t]{2}{*}{ Sex } & Male & 55 & 6 & 11 & 1 & 1.8 \\
\hline & Female & 133 & 27 & 20.3 & 9 & 6.7 \\
\hline \multirow{4}{*}{$\begin{array}{l}\text { Education } \\
\text { degree }\end{array}$} & Diploma & 57 & 10 & 17.5 & 2 & 3.5 \\
\hline & Graduate & 118 & 25 & 21.2 & 8 & 6.7 \\
\hline & Postgraduate & 10 & 0 & 0 & 0 & 0 \\
\hline & Doctoral & 3 & 0 & 0 & 0 & 0 \\
\hline \multirow[t]{6}{*}{ Occupation } & General practitoner & 1 & 0 & 0 & 0 & 0 \\
\hline & Resident & 78 & 12 & 15.4 & 6 & 7.7 \\
\hline & Specialist & 7 & 0 & 0 & 0 & 0 \\
\hline & Nurse & 96 & 20 & 20.8 & 3 & 3.1 \\
\hline & Midwife & 2 & 1 & 50 & 0 & 0 \\
\hline & Others & 4 & 2 & 50 & 1 & 25 \\
\hline \multirow[t]{2}{*}{ Workplace } & COVID Ward & 139 & 23 & 16.5 & 5 & 3.6 \\
\hline & Non COVID & 49 & 12 & 24.5 & 5 & 10.2 \\
\hline Marriage & Married & 134 & 21 & 16 & 4 & 3 \\
\hline \multirow[t]{3}{*}{ Status } & Single & 52 & 13 & 25 & 6 & 11.5 \\
\hline & Divorced & 1 & 0 & 0 & 0 & 0 \\
\hline & Widow & 1 & 0 & 0 & 0 & 0 \\
\hline \multirow{4}{*}{ Age (y/o) } & $21-30$ & 76 & 19 & 25 & 9 & 11.8 \\
\hline & $31-40$ & 73 & 11 & 15 & 0 & 0 \\
\hline & $41-50$ & 19 & 2 & 10.5 & 1 & 5.2 \\
\hline & $51-60$ & 20 & 3 & 15 & 0 & 0 \\
\hline
\end{tabular}

Pearson correlation analysis was conducted on the level of depression based on the results of the BDI associated with age, gender, last education, occupation, marital status, and location of service assignments, found a statistical relationship between depression levels with work and location of service assignments (Table 5).

Table 5

Correlation between depression and variables

\begin{tabular}{lc}
\hline Variable & $p$-value $:<0.05$ \\
\hline Age & 0.134 \\
Sex & 0.070 \\
Education Degree & 0.027 \\
Work field & 0.044 \\
Marriage Status & 0.144 \\
Workplace & 0.063 \\
\hline
\end{tabular}

Pearson correlation analysis was conducted based on anxiety levels based on BAI results associated with age, gender, last education, occupation, marital status, and location of service assignments, found a statistical relationship between depression level and location of service assignments (Table 6).

Ariani, N. K. P., Lesmana, C. B. J., Sitanggang, A. R. P., \& Pasaribu, I. L. M. (2022). Anxiety and depression disorders on health workers in COVID and non-COVID wards of Sanglah Hospital. International Journal of Health Sciences, 6(1), 21-31. https://doi.org/10.53730/ijhs.v6n1.3027 
Table 6

Correlation between anxiety and variables

\begin{tabular}{lc}
\hline Variable & $p$-value $:<0.05$ \\
\hline Age & 0.106 \\
Sex & 0.122 \\
Education Degree & 0.033 \\
Work field & 0.137 \\
Marriage Status & 0.142 \\
Work place & 0.064 \\
\hline
\end{tabular}

Most of the participants did not experience depression or experienced symptoms at least as much as $80 \%$ and who did not experience anxiety or with symptoms at least $70 \%$ of the participants. However, it was found that there was a mild depression of $1.6 \%$ among nurse participants, $2.1 \%$ of resident participants, and approximately $1 \%$ of midwives and other medical personnel. However, this must be looked at in more detail because of the unequal number of samples for each variable. Meanwhile, at the level of anxiety, $8.0 \%$ of nurses experienced mild anxiety, and some experienced severe anxiety (0.5\%) (Table 7 and Table 8).

Table 7

Depression level based on occupation

\begin{tabular}{llllll}
\hline \multirow{2}{*}{ Occupation } & \multicolumn{5}{c}{ Moderate } \\
\cline { 2 - 6 } & $\begin{array}{l}\text { None } \\
(\mathrm{n} ; \%)\end{array}$ & $\begin{array}{l}\text { Mild } \\
(\mathrm{n} ; \%)\end{array}$ & $\begin{array}{l}\text { Severe } \\
(\mathrm{n} ; \%)\end{array}$ & $\begin{array}{l}\text { Total } \\
(\mathrm{N}=188)\end{array}$ \\
\hline General practitoner & $1 ; 0.5$ & $0 ; 0$ & $0 ; 0$ & $0 ; 0$ & 1 \\
Resident & $72 ; 38.5$ & $4 ; 2.1$ & $1 ; 0.5$ & $1 ; 0.5$ & 78 \\
Specialist & $7 ; 3.7$ & $0 ; 0$ & $0 ; 0$ & $0 ; 0$ & 7 \\
Nurse & $93 ; 49.5$ & $3 ; 1.6$ & $0 ; 0$ & $0 ; 0$ & 96 \\
Midwife & $2 ; 1.1$ & $0 ; 0$ & $0 ; 0$ & $0 ; 0$ & 2 \\
Others & $3 ; 1.6$ & $0 ; 0$ & $1 ; 0.5$ & $0 ; 0$ & 4 \\
\hline
\end{tabular}

Table 8

Anxiety based on occupation

\begin{tabular}{|c|c|c|c|c|c|}
\hline Occupation & $\begin{array}{l}\text { None } \\
\text { (n) (\%) }\end{array}$ & $\begin{array}{l}\text { Mild } \\
\text { (n) (\%) }\end{array}$ & $\begin{array}{l}\text { Moderate } \\
\text { (n) }(\%)\end{array}$ & $\begin{array}{l}\text { Severe } \\
\text { (n) (\%) }\end{array}$ & $\begin{array}{l}\text { Total } \\
(\mathrm{N}=188)\end{array}$ \\
\hline General practitoner & $1 ; 0.5$ & $0 ; 0$ & $0 ; 0$ & $0 ; 0$ & 1 \\
\hline Resident & $66 ; 35.1$ & $8 ; 4.3$ & $1 ; 0.5$ & $1 ; 0.5$ & 78 \\
\hline Specialist & $7 ; 3.7$ & $0 ; 0$ & $0 ; 0$ & $0 ; 0$ & 7 \\
\hline Nurse & $76 ; 40.4$ & $15 ; 8.0$ & $4 ; 2.1$ & $1 ; 0.5$ & 96 \\
\hline Midwife & $1 ; 0.5$ & $0 ; 0$ & $1 ; 0.5$ & $0 ; 0$ & 2 \\
\hline Others & $2 ; 1.1$ & $0 ; 0$ & $2 ; 1.1$ & $0 ; 0$ & 4 \\
\hline
\end{tabular}

Table 9

Anxiety based on workplace

\begin{tabular}{|c|c|c|c|c|c|}
\hline Workplace (Ward) & $\begin{array}{l}\text { None } \\
\text { (n) (\%) }\end{array}$ & $\begin{array}{l}\text { Mild } \\
\text { (n) (\%) }\end{array}$ & $\begin{array}{l}\text { Moderate } \\
\text { (n) (\%) }\end{array}$ & $\begin{array}{l}\text { Severe } \\
\text { (n) (\%) }\end{array}$ & $\begin{array}{l}\text { Total } \\
(\mathrm{N}=188)\end{array}$ \\
\hline COVID Ward & $116 ; 61.7$ & $15 ; 8.0$ & $6 ; 3.2$ & $2 ; 1.1$ & 139 \\
\hline Non COVID Ward & $37 ; 19.7$ & $8 ; 4.3$ & $4 ; 2.1$ & $0 ; 0$ & 49 \\
\hline
\end{tabular}


Table 10

Depression based on workplace

\begin{tabular}{llllll}
\hline \multirow{2}{*}{ Workplace (Ward) } & $\begin{array}{l}\text { Mone } \\
\text { (n; \%) }\end{array}$ & $\begin{array}{l}\text { Mild } \\
(\mathrm{n} ; \%)\end{array}$ & $\begin{array}{l}\text { Moderate } \\
(\mathrm{n} ; \%)\end{array}$ & $\begin{array}{l}\text { Severe } \\
(\mathrm{n} ; \%)\end{array}$ & $\begin{array}{l}\text { Total } \\
(\mathrm{N}=188)\end{array}$ \\
\hline COVID Ward & $134 ; 71.3$ & $3 ; 1.6$ & $1 ; 0.5$ & $1 ; 0.5$ & 139 \\
Non COVID Ward & $44 ; 23.4$ & $4 ; 2.1$ & $1 ; 0.5$ & $0 ; 0$ & 49 \\
\hline
\end{tabular}

\subsection{Discussions}

According to research, both hereditary and non-genetic variables can cause generalized anxiety disorder. During a pandemic, those with personality problems or psychiatric disorders are more likely to have their symptoms exacerbated or worsened. Patients' anxiety symptoms are assumed to be triggered by non-genetic factors such as unpleasant experiences they face (Figley, 1995; Freudenberger, 1974). Several neurotransmitter systems in the frontal lobe and limbic system, including norepinephrine, GABAergic, and serotonergic systems, are thought to have a role in mediating this illness. The level of sadness and anxiety in health workers in the COVID and Non-COVID rooms at Sanglah Hospital was assessed in this study. It was found that there were levels of anxiety and depression in some health workers at Sanglah Hospital, although no real causal relationship was studied (McKay et al., 2006; Susilo et al., 2021). Studies in China show a high prevalence of depressive disorders and poor sleep quality in Chinese society during the COVID-19 outbreak (Centers for Disease Control and Prevention, 2020).

Anxiety symptoms are more likely to occur in people younger than 35 and those who spend too much time focusing on the pandemic. This is consistent with the findings in this study, that the highest levels of anxiety and depression were in the 21-30-year age group.

The study helps to understand the sources of public panic during the COVID-19 outbreak by providing data. Anxiety-related symptoms rose when a big infectious epidemic struck, according to data from a Chinese study. During the COVID-19 epidemic, it was shown that $1 / 3$ of participants had anxiety and mood disorders, which was not different between men and women, unlike prior research that revealed women to be more likely to have anxiety than males (Su \& Chen, 2007; Guo et al., 2016; Gao et al., 2020). In addition, roughly onefifth of the participants exhibited depression and sleep problems. This is also in line with the findings of this study, albeit more research on the subject is needed.

Shortness of breath can be exacerbated by major psychological burdens such as anxiety, generalized anxiety disorder, and panic attacks, as well as aggressive behavior by the patient that leads to non-compliance and anxiety towards medical personnel, obsessive behavior that can lead to medical personnel dysfunction, depression, and sleep disturbances. Coronaphobia is a word used in the psychiatric literature to describe an extreme dread of contracting SARS-COV2 or COVID 19 infection. Influenza infection, having a close member or friend afflicted with the virus, and a strong fear of infection have all been shown as significant predictors of posttraumatic stress disorder (Ouassou et al., 2020; Lakhan et al., 2020; Li et al., 2020).

Chen et al. (2020), report another significant source of stress among healthcare providers in China is the stress of having to treat a COVID-19 patient while carrying the fear of being infected, or of being a contact who spreads the infection to their loved ones. In addition, fearful of the lack of personal protective equipment, these health workers face difficulties dealing with emotionally depressed COVID-19 patients and feelings of inadequacy, while caring for critically ill or dying patients (Polizzi et al., 2020; Walton et al., 2020). This is slightly inconsistent with what was found in the study, where there was a higher level of anxiety in participants who worked in the non-COVID room compared to the COVID room. The possibility of a sense of security in the COVID room with all the complete supporting equipment (google, hazmat, gloves, aprons, etc.) when compared to the non-COVID room, where apart from incomplete equipment due to room division and the number of waiting patients has been limited, there is still the possibility of spread. This can be studied again in further research (Wu et al., 2020; Wu \& McGoogan, 2020).

The research revealed that providing social support to health care professionals is a crucial social component that can help them cope with stress and anxiety, improve their sleep quality, and boost their self-

Ariani, N. K. P., Lesmana, C. B. J., Sitanggang, A. R. P., \& Pasaribu, I. L. M. (2022). Anxiety and depression disorders on health workers in COVID and non-COVID wards of Sanglah Hospital. International Journal of Health Sciences, 6(1), 21-31. https://doi.org/10.53730/ijhs.v6n1.3027 
efficacy (Xiao et al., 2020; Widana et al., 2021). As a result, social support enables healthcare workers to keep relatively stable emotions, allowing them to cope more effectively with work constraints.

Setting up psychological intervention services, such as online courses, hotline services, and on-site psychological counselors, was one of the initiatives done by relevant governmental authorities in response to demand from healthcare practitioners during the COVID-19 outbreak in China (Tolmacheva et al., 2021). Other support measures include providing lodging for workers to rest, giving food and other daily essentials, and allowing staff to video record their daily routines with their loved ones to alleviate family stress (Asman et al., 2021). This demonstrates the health authorities' investment in improving frontline workers' abilities to cope with the demanding demands of their jobs. Increases in social capital, which is defined as a pool of both current and potential resources that includes social trust, belonging, and involvement, are also required to foster economic growth.

\section{Limitations}

This research requires improvements in the future in the form of improving methods where the identification of syndromes or symptoms of psychiatric disorders such as anxiety and depression can be explored as well as their real relationship with the workload of health workers at Sanglah Hospital during the pandemic. If possible, the sample is expanded not only in one center but can be carried out in a multicenter so that the data obtained is more complete and can make a more thorough analysis.

The analytical method used can also be developed based on the research objectives to be obtained so that a causal or causal relationship can be obtained from the emergence of anxiety and depression disorders in health workers in the COVID and Non-COVID rooms. The development of this research can also be developed as a benchmark to measure the safety and comfort of medical personnel at Sanglah Hospital in working, especially during the pandemic so that the pressure at work can be managed properly with support from the hospital.

\section{Conclusion}

There are health workers on duty at Sanglah Hospital who experience anxiety and depression. And it was found that the incidence of anxiety and depression was higher in the Non-COVID room at Sanglah Hospital compared to the COVID room. It is hoped that health workers will be aware of the symptoms experienced and seek help so that appropriate interventions can be given on time. Further research to determine other factors that play a role in influencing the level of anxiety and depression needs to be investigated further in the future.

\section{Acknowledgments}

We are grateful to two anonymous reviewers for their valuable comments on the earlier version of this paper. 


\section{References}

Akbarov, A. N., \& Xabilov, D. N. U. (2021). The condition of the oral cavity in patients who have had a viral infection COVID-19. International Journal of Health \& Medical Sciences, 4(4), 381-383.

Asman, A., Asman, A., \& Dewi, A. K. (2021). Community nursing strategies for tourism health families during COVID-19 pandemic. International Journal of Health Sciences, 5(3), 224-231. https://doi.org/10.53730/ijhs.v5n3.1449

Brooks, S. K., Webster, R. K., Smith, L. E., Woodland, L., Wessely, S., Greenberg, N., \& Rubin, G. J. (2020). The psychological impact of quarantine and how to reduce it: rapid review of the evidence. The lancet, 395(10227), 912-920. https://doi.org/10.1016/S0140-6736(20)30460-8

Burdorf, A., Porru, F., \& Rugulies, R. (2020). The COVID-19 (Coronavirus) pandemic: consequences for occupational health. Scandinavian Journal of Work, Environment \& Health, 46(3), 229-230.

Centers for Disease Control and Prevention. (2020). Centers for Disease Control and Prevention Coronavirus disease 2019 (COVID-19) 2020.

Chen, G., Wu, Q., Jiang, H., Zhang, H., Peng, J., Hu, J., ... \& Xie, C. (2020). Fear of disease progression and psychological stress in cancer patients under the outbreak of COVID-19. Psycho-oncology.

Del Rio, C., \& Malani, P. N. (2020). COVID-19-new insights on a rapidly changing epidemic. Jama, 323(14), 1339-1340.

Dyrbye, L. N., Thomas, M. R., Massie, F. S., Power, D. V., Eacker, A., Harper, W., ... \& Shanafelt, T. D. (2008). Burnout and suicidal ideation among US medical students. Annals of internal medicine, 149(5), 334-341.

Figley, C. R. (1995). Compassion fatigue: Toward a new understanding of the costs of caring.

Freudenberger, H. J. (1974). Staff burn-out. Journal of social issues, 30(1), 159-165.

Gao, W., Ping, S., \& Liu, X. (2020). Gender differences in depression, anxiety, and stress among college students: a longitudinal study from China. Journal of affective disorders, 263, 292-300. https://doi.org/10.1016/j.jad.2019.11.121

Guo, X., Meng, Z., Huang, G., Fan, J., Zhou, W., Ling, W., ... \& Su, L. (2016). Meta-analysis of the prevalence of anxiety disorders in mainland China from 2000 to 2015. Scientific reports, 6(1), 1-15.

Haines, A., Sanders, D., Lehmann, U., Rowe, A. K., Lawn, J. E., Jan, S., ... \& Bhutta, Z. (2007). Achieving child survival goals: potential contribution of community health workers. The lancet, 369(9579), 2121-2131. https://doi.org/10.1016/S0140-6736(07)60325-0

Huang, Y., \& Zhao, N. (2020). Generalized anxiety disorder, depressive symptoms and sleep quality during COVID-19 outbreak in China: a web-based cross-sectional survey. Psychiatry research, 288, 112954. https://doi.org/10.1016/j.psychres.2020.112954

Lakhan, R., Agrawal, A., \& Sharma, M. (2020). Prevalence of depression, anxiety, and stress during COVID-19 pandemic. Journal of neurosciences in rural practice.

Li, Z., Ge, J., Yang, M., Feng, J., Qiao, M., Jiang, R., ... \& Yang, C. (2020). Vicarious traumatization in the general public, members, and non-members of medical teams aiding in COVID-19 control. Brain, behavior, and immunity, 88, 916-919. https://doi.org/10.1016/j.bbi.2020.03.007

Martini, S., Arfken, C. L., Churchill, A., \& Balon, R. (2004). Burnout comparison among residents in different medical specialties. Academic psychiatry, 28(3), 240-242.

McKay, K. M., Imel, Z. E., \& Wampold, B. E. (2006). Psychiatrist effects in the psychopharmacological treatment of depression. Journal of affective disorders, 92(2-3), 287-290. https://doi.org/10.1016/j.jad.2006.01.020

Nanda, A. (2020). Physician wellness in allergy and immunology: personal resiliency. Annals of Allergy, Asthma \& Immunology. https://doi.org/10.1016/j.anai.2020.10.018

Nanjundaswamy, M. H., Pathak, H., \& Chaturvedi, S. K. (2020). Perceived stress and anxiety during COVID-19 among psychiatry trainees. Asian journal of psychiatry, 54, 102282.

Neumann, M., Edelhäuser, F., Tauschel, D., Fischer, M. R., Wirtz, M., Woopen, C., ... \& Scheffer, C. (2011). Empathy decline and its reasons: a systematic review of studies with medical students and residents. Academic medicine, 86(8), 996-1009.

Ouassou, H., Kharchoufa, L., Bouhrim, M., Daoudi, N. E., Imtara, H., Bencheikh, N., ... \& Bnouham, M. (2020). The pathogenesis of coronavirus disease 2019 (COVID-19): evaluation and prevention. Journal of immunology research, 2020.

Polizzi, C., Lynn, S. J., \& Perry, A. (2020). Stress and coping in the time of COVID-19: pathways to resilience and recovery. Clinical Neuropsychiatry, 17(2).

Ariani, N. K. P., Lesmana, C. B. J., Sitanggang, A. R. P., \& Pasaribu, I. L. M. (2022). Anxiety and depression disorders on health workers in COVID and non-COVID wards of Sanglah Hospital. International Journal of Health Sciences, 6(1), 21-31. https://doi.org/10.53730/ijhs.v6n1.3027 
Rose, C. (2020). Am I part of the cure or am I part of the disease? Keeping coronavirus out when a doctor comes home. New England Journal of Medicine, 382(18), 1684-1685.

Shanafelt, T. D., Boone, S., Tan, L., Dyrbye, L. N., Sotile, W., Satele, D., ... \& Oreskovich, M. R. (2012). Burnout and satisfaction with work-life balance among US physicians relative to the general US population. Archives of internal medicine, 172(18), 1377-1385.

$\mathrm{Su}$, L. H., \& Chen, T. H. H. (2007). Association of androgenetic alopecia with smoking and its prevalence among Asian men: a community-based survey. Archives of dermatology, 143(11), 1401-1406.

Susilo, C. B., Jayanto, I., \& Kusumawaty, I. (2021). Understanding digital technology trends in healthcare and preventive strategy. International Journal of Health \& Medical Sciences, 4(3), 347-354.

Tan, B. Y., Chew, N. W., Lee, G. K., Jing, M., Goh, Y., Yeo, L. L., ... \& Sharma, V. K. (2020). Psychological impact of the COVID-19 pandemic on health care workers in Singapore. Annals of internal medicine, 173(4), 317-320.

Tetro, J. A. (2020). Is COVID-19 receiving ADE from other coronaviruses?. Microbes and infection, 22(2), 72-73. https://doi.org/10.1016/j.micinf.2020.02.006

Tolmacheva, S., Tkachev, A., \& Shamshin, M. (2021). The impact of the pandemic on moral panics in society. International Journal of Health Sciences, 5(3), 232-243. https://doi.org/10.53730/ijhs.v5n3.1485

Walton, M., Murray, E., \& Christian, M. D. (2020). Mental health care for medical staff and affiliated healthcare workers during the COVID-19 pandemic. European Heart Journal: Acute Cardiovascular Care, 9(3), 241247.

Warren, S. L., Huston, L., Egeland, B., \& Sroufe, L. A. (1997). Child and adolescent anxiety disorders and early attachment. Journal of the American Academy of Child \& Adolescent Psychiatry, 36(5), 637-644. https://doi.org/10.1097/00004583-199705000-00014

Widana, I.K., Sumetri, N.W., Sutapa, I.K., Suryasa, W. (2021). Anthropometric measures for better cardiovascular and musculoskeletal health. Computer Applications in Engineering Education, 29(3), 550561. https://doi.org/10.1002/cae.22202

Wu, Y., Wang, J., Luo, C., Hu, S., Lin, X., Anderson, A. E., ... \& Qian, Y. (2020). A comparison of burnout frequency among oncology physicians and nurses working on the frontline and usual wards during the COVID-19 epidemic in Wuhan, China. Journal of pain and symptom management,60(1), e60-e65. https://doi.org/10.1016/j.jpainsymman.2020.04.008

Wu, Z., \& McGoogan, J. M. (2020). Characteristics of and important lessons from the coronavirus disease 2019 (COVID-19) outbreak in China: summary of a report of 72314 cases from the Chinese Center for Disease Control and Prevention. Jama, 323(13), 1239-1242.

Xiao, H., Zhang, Y., Kong, D., Li, S., \& Yang, N. (2020). The effects of social support on sleep quality of medical staff treating patients with coronavirus disease 2019 (COVID-19) in January and February 2020 in China. Medical science monitor: international medical journal of experimental and clinical research,26, e923549-1. 


\section{Biography of Authors}

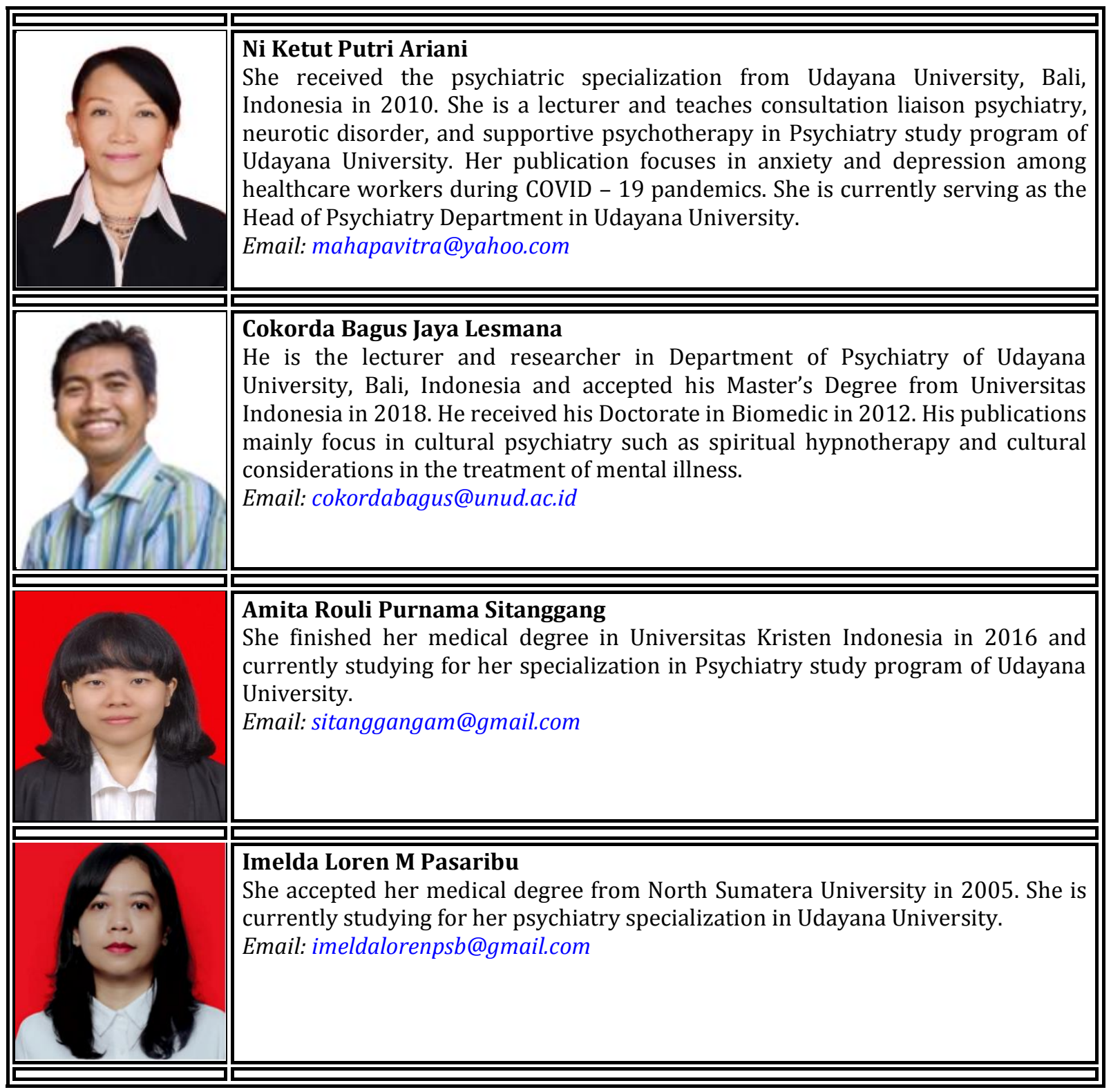

Ariani, N. K. P., Lesmana, C. B. J., Sitanggang, A. R. P., \& Pasaribu, I. L. M. (2022). Anxiety and depression disorders on health workers in COVID and non-COVID wards of Sanglah Hospital. International Journal of Health Sciences, 6(1), 21-31. https://doi.org/10.53730/ijhs.v6n1.3027 